Espacio, Tiempo y Forma, Serie VII, H. ${ }^{a}$ del Arte, t. 6, 1993, págs. 149-174

\title{
Murallas para la guerra y para la paz. Imágenes de la ciudad en la España del siglo XVI
}

\author{
Alicia Cámara Muñoz *
}

En el capítulo tercero del primero de los diez libros de arquitectura de Vitruvio, podemos leer que:

“Las distribuciones de los edificios públicos son tres... Distribución de defensión es una razón de muros, y torres, y puertas para defender los ímpetus, y combate de los enemigos perpetuamente. Distribución de religión es un assiento de casas sagradas, de templos de dioses immortales. Distribución de commodidad, es una disposición de lugares públicos, como son puertos, mercados, portales, vaños, theatros, passeaderos, y todas las demas cosas desta manera, las quales se suelen edificar en lugares públicos"' ".

Esta declaración sobre lo que eran los edificios públicos fue aplicada como marco para sus argumentos por escritores que desde distintos planteamientos se ocuparon de las obras públicas. Lo primero sobre lo que queremos llamar la atención es sobre lo siguiente: si repasamos los es-

* Dpto. H. ${ }^{a}$ del Arte. UNED.

Vitruvio, M. De Architectura, dividido en diez libros, traduzidos de Latín en Castellano por Miguel de Urrea... Alcalá de Henares 1582, f. $11 v^{\circ}$. Sobre la ambigüedad de algunos términos en las ediciones de Vitruvio y en la tratadística del siglo xvi, podemos referirnos a cómo la "comodidad" fue considerada condición necesaria a las obras públicas - por ejemplo los puentes- en el sentido en que se utiliza en la citada traducción al castellano de Vitruvio. Así en Pseudo Juanelo Turriano, Los veintiún libros de los ingenios y de las máquinas. Madrid 1983, págs. 421 y 422 . Sin embargo en Italia el concepto de "commodità" parece adueñarse en algún caso de todo lo que es arquitectura, y asi por ejemplo B. Cellini escribirá que, de las tres partes necesarias a ésta, la segunda es la "commodità», que deben tener un templo, un palacio, un anfiteatro, una fortaleza o una ciudad (CELLINI, B., Opere, Vita, Trattati, Rime, Lettere. Milano 1968, pág. 856). Para Palladio también la "commodità" va más allá de lo que son algunos edificios públicos, para convertirse en algo necesario a cualquier edificio pues identifica la «utilitas" vitruviana (l'utile) con la "commodità" (PALLADIO, A.,/quattro primi libri dell'architettura. Venecia 1570, pág. 6). 
tudios sobre arquitectura del Renacimiento en España, lo normal es que encontremos una división entre arquitectura civil y arquitectura religiosa, dándole a esta última una autonomía y un protagonismo que sin duda viene justificado tanto por la envergadura del patrimonio conservado, como por el papel de la iglesia en la sociedad. Queda así la arquitectura civil convertida en un saco en el que cabe tanto lo público como lo privado. Sin embargo, si lo que nos planteamos es el tema de la ciudad y los hombres que la habitaron, la división vitruviana entre lo público y lo privado parece más adecuada y así lo entendieron algunos de los que escribieron sobre ello en el siglo xvı.

Efectivamente, la división vitruviana entre edificios públicos y particulares fue un lugar común en muchos de los textos del siglo xvı. Por ejemplo Cristóbal de Rojas, en su tratado sobre fortificación del año 1598, sólo incluía aquello de la arquitectura que consideraba necesario para el ingeniero y para los arquitectos «que se encargan de templos, y otras otras públicas» $y$, en otro momento, escribía «... y bolviendo a mi particular de las fábricas, assí de fortificación, como de templos, y otras obras públicas..." ${ }^{2}$. También cuando Francisco del Castillo concursó en 1577 a la maestría mayor de la catedral de Granada declaró entre sus méritos haber hecho "templos y fortalezas y casas de consistorio puentes fuentes y otra mucha diversidad de edificios públicos", además de edificios privados ${ }^{3}$.

Un libro tan leído y manejado como fue la Política para Corregidores, de Castillo de Bobadilla, aunque no abordaba de manera específica el tema de la arquitectura $-\mathrm{y}$ precisamente por ello es más esclarecedor sobre lo que venimos diciendo-empleaba la división vitruviana sobre los edificios públicos al referirse a las funciones del corregidor, que tenía precisamente en lo público su ámbito de actuación. Consideraba edificios públicos a las iglesias, siendo una de las funciones del corregidor el incitar a la Iglesia a la construcción de templos, pero también se debía ocupar de muros, castillos, fortalezas, calzadas, fuentes, puentes, cárceles, casas de ayuntamiento, tribunales de justicia, pósitos, carnicerías, pescaderías, panaderías... Actualizaba así el tipo de edificios con respecto a los de la antigüedad que citaba Vitruvio, pero se mantenía dentro de la idea vitruviana. El corregidor consultaría para las obras con el arquitecto o alarife que se hubiera contratado como maestro de obras, pero él mismo debía tener conocimientos de aritmética, pintura y geometría para no tener que

2 Rojas, C. de, Teórica y práctica de fortificación. Madrid 1598. fol. $88 v^{\circ}$ y 97.

3 Gallego y Burin, El Barroco granadino, pág. 64 y Moreno Mendoza, A., Francisco del Castillo y la arquitectura manierista andaluza. Jaén 1984, pág. 358. 
«remitirse vergonçosamente, y por inorancia, al parecer de contadores, o de artífices, y descargarse con ellos como peritos en el arte" ${ }^{4}$. Estudiar hasta qué punto los corregidores intervinieron en las decisiones sobre las obras públicas nos llevaría a plantearnos algo tan poco estudiado como es el papel determinante que hombres que no fueron arquitectos jugaron en la evolución del gusto en el siglo xvl.

De lo que llevamos dicho se deduce que las murallas eran parte de esos edificios públicos sobre los que se construía la grandeza de una ciudad. Si la construcción de edificios públicos estaba sujeta a una serie de reglas de contratación, que Castillo de Bobadilla explicaba con claridad y que estaban por encima de los intereses particulares, también el estado de las murallas debía ser controlado por el corregidor -aconsejado por ingenieros y personas entendidas en fortificación - en las ciudades de presidio o frontera. En este sentido podemos recordar cómo cuando en 1577 se ordenó al ingeniero Juan Bautista Antonelli que continuara con la traza que habian decidido el rey y el Consejo de Guerra para Cádiz - después de haber visto tanto el parecer de Antonelli como los que anteriormente habían dado Calvi y Fratín - fue Diego de Benavides, corregidor de aquella ciudad, el encargado de hacer ejecutar la instrucción y proseguir la fortificación ${ }^{5}$.

Las nuevas fortificaciones de las ciudades del siglo XVI estuvieron por encima tanto de intereses particulares, como municipales o de la iglesia, pues lo que en ellas se materializaba no afectaba sólo a la defensa de la ciudad, sino a la de la misma monarquia. Desde el punto de vista del urbanismo las murallas condicionaron el desarrollo de la ciudad a veces durante siglos. Los perímetros amurallados se renovaron o hicieron nuevos con fines de defensa en aquellas que eran ciudades de frontera, pero también se proyectaron murallas con una finalidad que trascendió la pura función defensiva. De nuevo las palabras de Castillo de Bobadilla pueden ser útiles para abordar este tema: después de recordar la polémica existente sobre "si conviene, o no, que la ciudad esté murada", concluye que las murallas son necesarias sobre todo en España tanto por el odio que despierta su Imperio "como por la natural inquietud, y ardiente cólera desta nación», que puede dar lugar a "guerras civiles». Esto por lo que se refiere a las murallas que tienen un fin defensivo, pero son también importantes los muros "por el mucho lustre y ornato que se sigue de estar las fortalezas y murallas enteras, y con almenas ${ }^{6}$, argumento que, como

4 Castillo de Bobadilla, Política para corregidores, ed. de 1597, passim, el texto citado en la pág. 126.

5 Aachivo General de Simancas (AGS), Guerra Antigua (GA), leg. 88, fol. 164.

6 Castillo de Bobadilla, op. cit., págs. 564 a 567 
veremos, será utilizado por Cristobal Pérez de Herrera cuando proponga la construcción de una nueva muralla para Madrid.

Las murallas, bien para la guerra, bien para la paz, configuraron una imagen urbana, desdibujada en muchos casos por la extensión de los arrabales - sobre todo en las ciudades del interior peninsular en las que esos muros habían perdido su carácter defensivo- pero protagonista en otros tal como vamos a ver.

\section{MURALLAS PARA LA GUERRA}

Las puertas en las murallas de las ciudades y ciudadelas fueron un elemento urbano de primer orden por ser el acceso a un espacio acotato por unos muros que, cualquiera que fuera su finalidad, establecían un fuera y un dentro con un único elemento permeable que era la puerta. Cargadas de simbolismo, en ellas hay dos aspectos esenciales: los escudos con su mensaje de poder y unos almohadillados que las convierten en fragmentos arquitectónicos capaces de expresar por sí mismos la fuerza de lo que guardan. Ejemplo de ello puede ser la puerta de la fortificación de Ibiza, cuya inscripción en latín recuerda que fue hecha durante el reinado de «Philippo rege catholico invictissimo Hispaniarum indiarum...", siendo gobernador Fernando Zanoguera, el año $1585^{7}$. Muchos años antes Francisco de Villalpando en las líneas de «el intérprete al lector» de su traducción de los libros III y IV de Serlio- escribía que al poner las armas o estatuas de los fundadores en los edificios «parece que cada piedra... está diziendo y representando la persona, la magestad, el pontificado y autoridad del fundador" ${ }^{8}$. La de Ibiza muestra hasta que punto era cierta esa afirmación.

Hubo un tipo de puertas, como la del arco de Santa María en Burgos, hecha entre 1531 y 1553 para conmemorar la entrada del emperador en la ciudad en $1520^{\circ}$, que recuerdan más los arcos triunfales de las fiestas a pesar de su carácter de fortaleza. Transformadoras de la imagen de la ciudad, es frecuentemente la única parte de la muralla urbana que el hombre de la época percibe claramente al aproximarse a la ciudad, así que en ellas se han de condesar los significados de poder que se quieren transmitir, utilizándose para ello un lenguaje concreto: lo más frecuente

7 Sobre esta puerta, POSADAS López, E.J., Las murallas de Ibiza. Ibiza 1989, págs. 153-156

Serlio, Tercero y Quarto libro de Architectura. Toledo 1552.

9 González de Santiago, I., "El arco de Santa María en Burgos", BSAA, LV, 1989 pág. 289. 


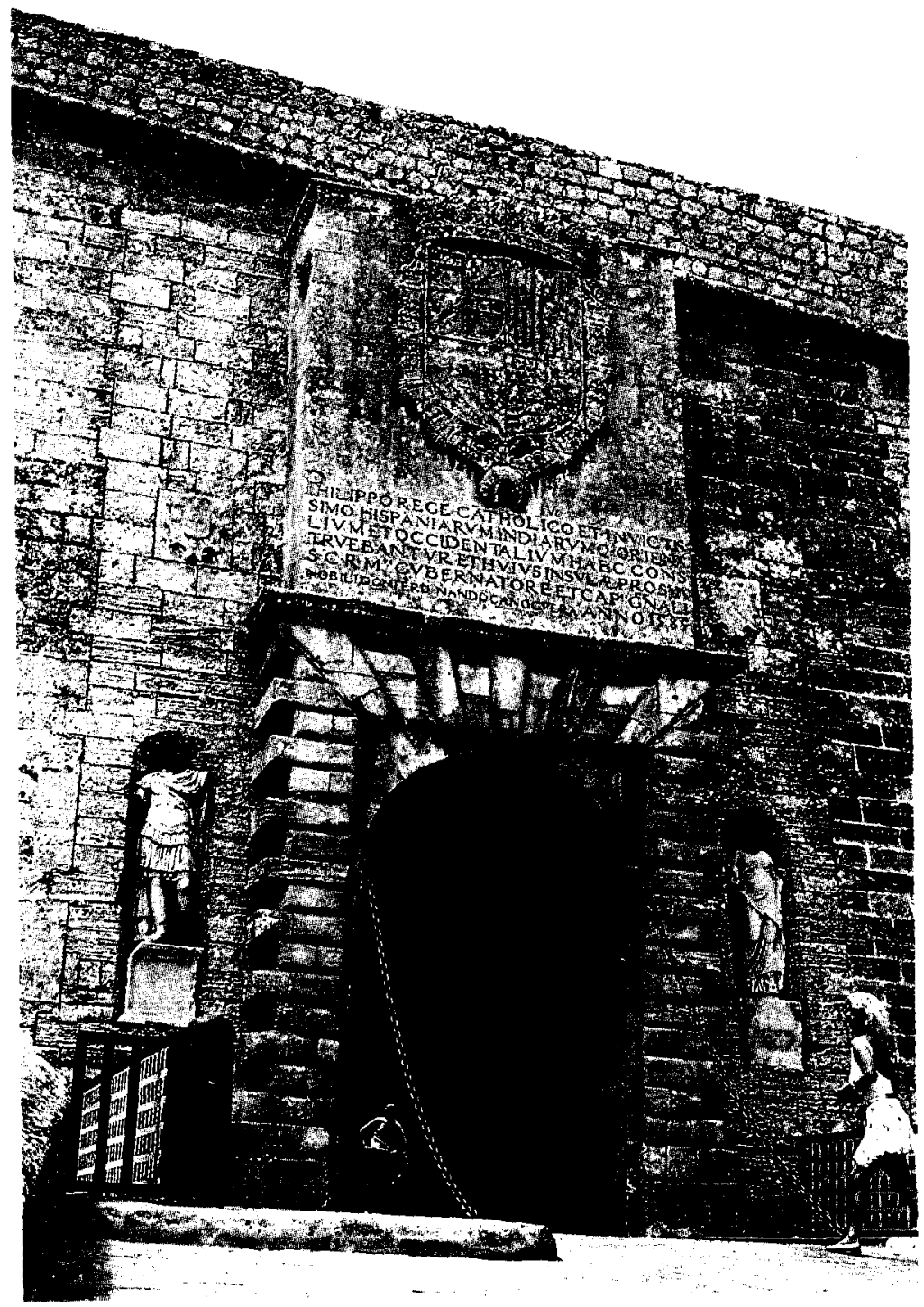

Fig. 1. Puerta del Mar. Ibiza, 1585. 


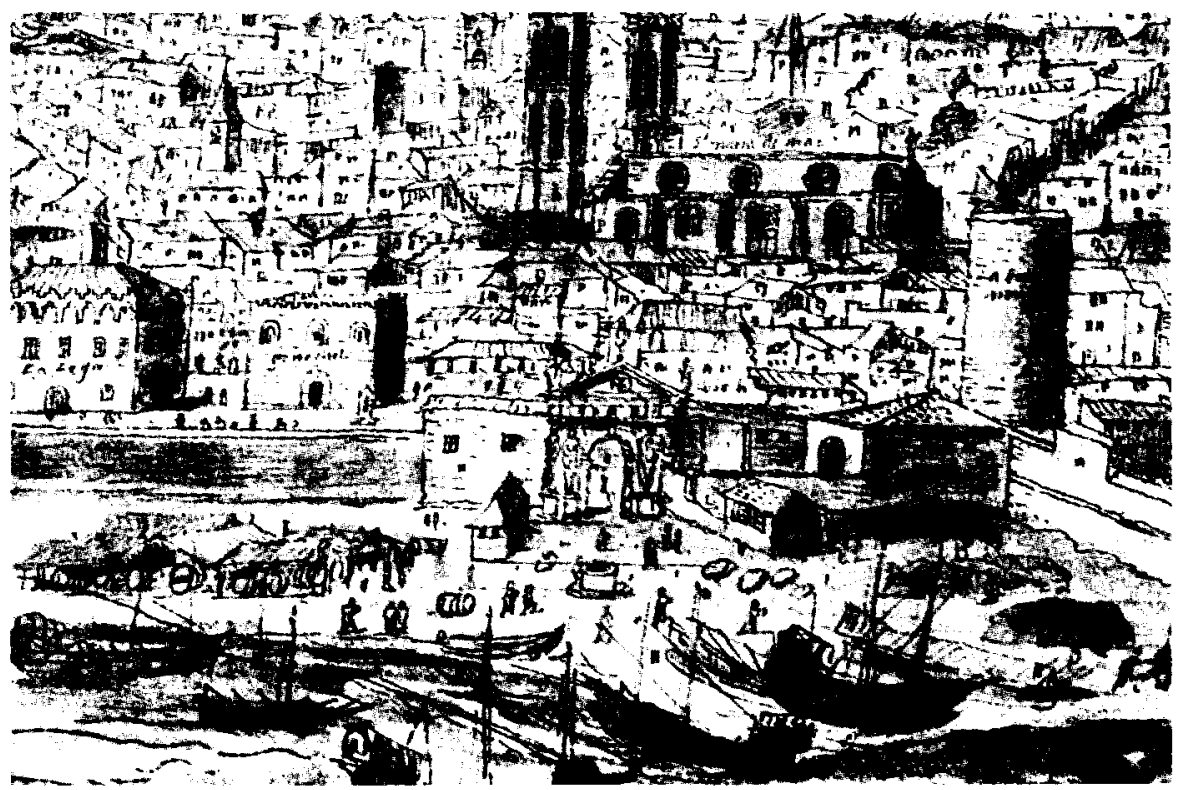

Fig. 2. Vista de Barcelona en 1563 por Anton Van den Wyngaerde en la que se puede apreciar la Puerta de la Marina, o Portal del Mar.

fue un fuerte almohadillado a la rústica, tal como se hizo en la puerta de la fortaleza de Perpiñán -atribuida a Jorge Setara- en 1577 y que llevaba las armas del rey y del duque de Alba, apareciendo en ellas hermes.

Esta utilización de la figura humana sustituyendo a la columna o a la pilastra en las puertas de las fortificaciones, fue algo incluso recogido en los tratados. En concreto Francesco de Marchi recogía en su libro segundo lo que había escrito Vitruvio acerca de la derrota de los persas y cómo las cariátides o los hermes en las fachadas alegraban la vista del hombre ${ }^{10}$, pero yendo a los orígenes de esta historia - esto es, Vitruvio- es como podemos comprender que precisamente en puertas de ciudades 0 ciudadelas destinadas a conservar la perpetua memoria de poderosos monarcas como Carlos V o Felipe II se utilizarn hermes o cariátides ya que, en ambos casos y según nos relata Vitruvio, dichas figuras en su origen conmemoraron victorias militares. En Barcelona la puerta de la marina o portal del mar, realizado a mediados de siglo, presentaba un

10 MaRchI, F. de, Della architettura militare, libro II, fol. 29. 
elemento figurativo dominante que eran precisamente las cariátides. Esta puerta se ha atribuido al ingeniero milanés Juan Bautista Calvi, llegado a España a mediados de siglo después de trabajar en Milán y Siena, cuyo nombre aparece relacionado también en cierto momento con las reformas llevadas a cabo en la Alhambra de Granada.

Aunque en 1588 el Consejo de Guerra informaba al rey de que mucho más necesario era atender a las fortificaciones de Cádiz y de Gibraltar que a las obras de la Alhambra y del Alcázar de Sevilla (consideradas fortalezas y no palacios), en la primera se emprendieron algunas obras de importancia. El punto de partida es precisamente la consideración del recinto de la Alhambra como una fortificación, por lo cual algunas obras dependían del Consejo de Guerra. Por eso los miembros de este Consejo opinaban que no se debían reparar en ella las "cossas antiguas que se hizieron para otro orden y modo de defensa de guerra, que agora se platica" ", refiriéndose al tipo de fortificación ahora ya inoperante. Sin embargo, y como lugar emblemático que era para la monarquía, de la misma manera que se hizo un palacio, también a la Alhambra se la dotó con una puerta que hubiera sido digna de la mejor fortificación de la Europa occidental a mediados del siglo xvı. De esta puerta de las Granadas se conocen documentos referentes al labrado del escudo por Juan de Orea en 1552. Rosenthal ha apuntado que la traza de esta puerta quizá fuera aprobada antes de 1550 , pero no la considera atribuible a Pedro Machuca debido a sus rasgos estilísticos, y piensa que quizá fuera realizada en la década de 1590. Como hipótesis se podría plantear también la posible intervención de Luis Machuca en la traza, pues en 1552 fue nombrado maestro mayor de la Alhambra y era hombre entendido en el tema de la fortificación, como demostró ocupándose de las fortificaciones de la costa. Sin embargo, dada la importancia de la obra, se podría pensar que la opinión de un ingeniero de la talla de Calvi también pesó en la decisión acerca del modelo de puerta adecuado a esta fortaleza. De hecho sabemos que en 1557 Luis Machuca llevó la traza de la fortificación de la Alhambra a Cádiz para que la viera "Juan Bautista, yngenero de su magestad" ${ }^{12}$. No se trata de Juan Bautista de Toledo, como se ha pensado (que además en esa fecha no estaba en España), sino de Juan Bautista Calvi, y lo cierto es que todo en esa puerta nos remite a un ingeniero de fortificación.

"AGS, GA, leg. 234, fol. 233.

12 Tanto este dato como otros de los que se han citado, en RosenthaL. E.E., El palacio de Carlos V en Granada. Madrid 1988, págs. 105 y 129-131. 


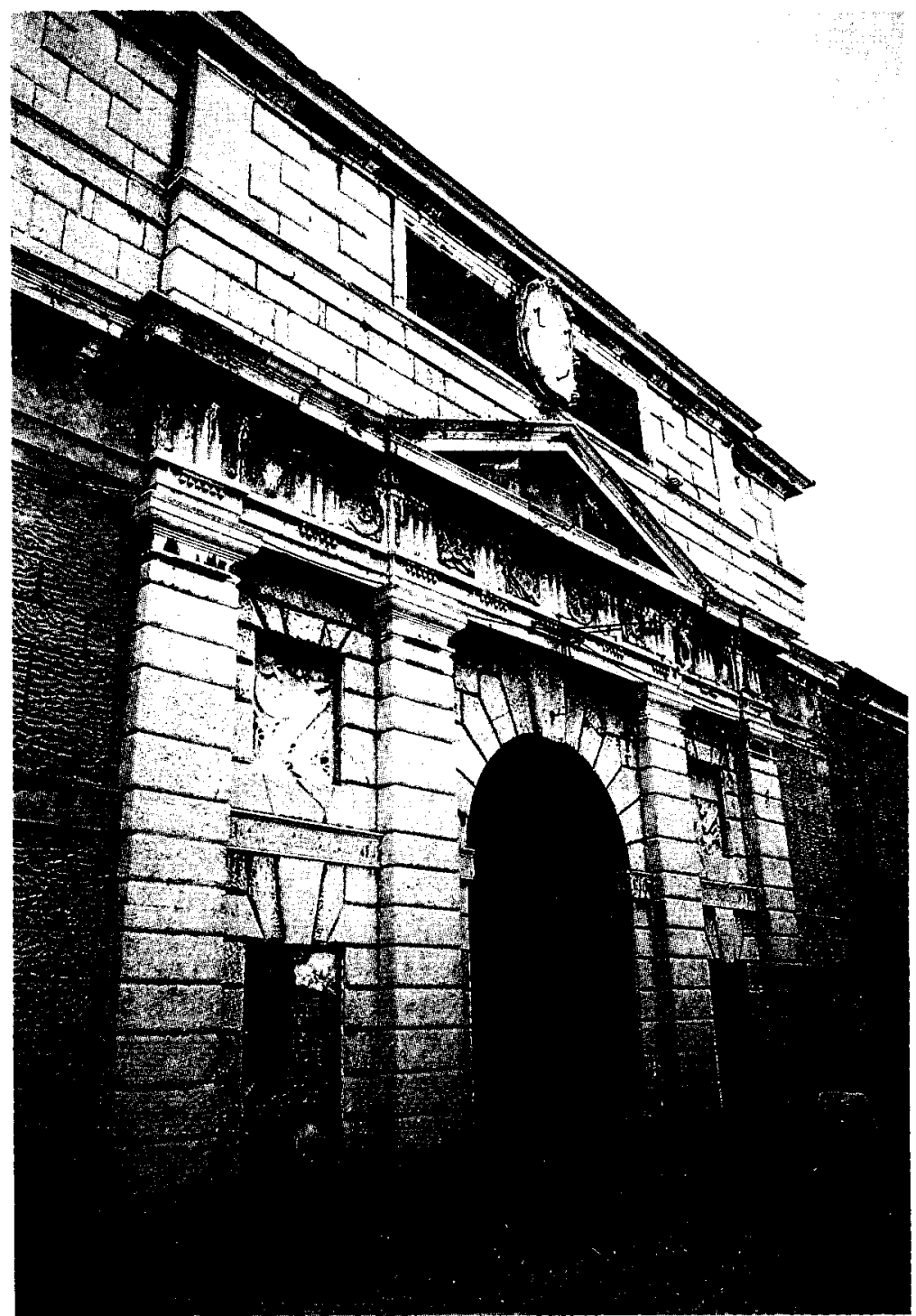

Fig. 3. Puerta de Giulio Romano en la ciudadela de Mantua. 
Es una puerta que recuerda a las de Giulio Romano y a las puertas de ornamento rústico a las que se refería Serlio en su IV libro como las más adecuadas para «puertas de ciudades, para fortalezas, para castillos y lugares para guardar tesoros, y adonde estén las municiones y artillerías, o para cárceles y puertos de mar y otros semejantes edificios para uso de la guerra". Además en esta puerta se mezcla, tal como recomienda Serlio, obra artificial y obra "de natura", pues arquitrabe y frontispicio «representan obra hecha por mano» y «las colunas faxadas de las piedras rústicas... muestran obra de naturaleza", con lo cual -como dice este tratadista de ese tipo de puertas - resulta muy agradable a los ojos a la vez que muestra su gran fortaleza, siendo una puerta muy apropiada para una fortaleza o castillo que - añadimos nosotros - es el caso de la Alhambra. En esta puerta se cumplió también la norma dada por Serlio acerca de las puertas de ciudades, como era el que "quanto fuere mas gruessamente ladrada: tanto más mostrara su fortaleza y bravosidad" ${ }^{13}$.

El modelo serliano - aunque mediatizado por los grandes torreones que flanquean la puerta y casi aplastado por la majestad del escudo imperial - también se ha querido ver en la toledana puerta de Bisagra. La puerta de la ciudadela de Amberes era una de las partes más acabadas en el grabado de 1577 de esta ciudadela paradigmática trazada por Paciotto. En un plano teórico, en el tratado de Cristóbal de Rojas se proponía un modelo bastante modesto, pero arquetípico, para puertas de fortificación que había quedado reducido a un potente almohadillado y al escudo con las armas. Mucho más elaborada era la portada de este tratado, en la que vemos el refinamiento alcanzado por el lenguaje arquitectónico de las puertas, con sus columnas fajadas, el frontón partido para el gran escudo y los remates de pirámides con bolas de los extremos del cuerpo inferior. Precisamente este último elemento lo podemos ver también en la puerta que en 1613 se estaba haciendo para la ciudadela de Jaca - siguiendo el modelo de la de Pamplona- donde de nuevo el almohadillado y el escudo definían el esquema establecido para puertas de fortificaciones. No son estas las únicas puertas nuevas o renovadas en el siglo $\mathrm{XVI}^{14}$, pero pueden servir como ejemplo del peso tanto de la tratadística como de la arquitectura militar en la creación de una nueva imagen urbana.

Dejando ya las puertas para ieferirnos propiamente a los recintos amurallados, es sintomático que un tratadista como Cristóbal de Rojas -re-

13 Las citas de Serlio en op. cit., (1552) libro IV, fols. IV, XI y XIII ${ }^{\circ}$

14 Marias. F., "Las ciudades del siglo XVi y el urbanismo renacentista", en KAGaN, R.L., Ciudades del Siglo de Oro. Las vistas españolas de Anton van den Wyngaerde. Madrid 1986, págs. 99-100. 


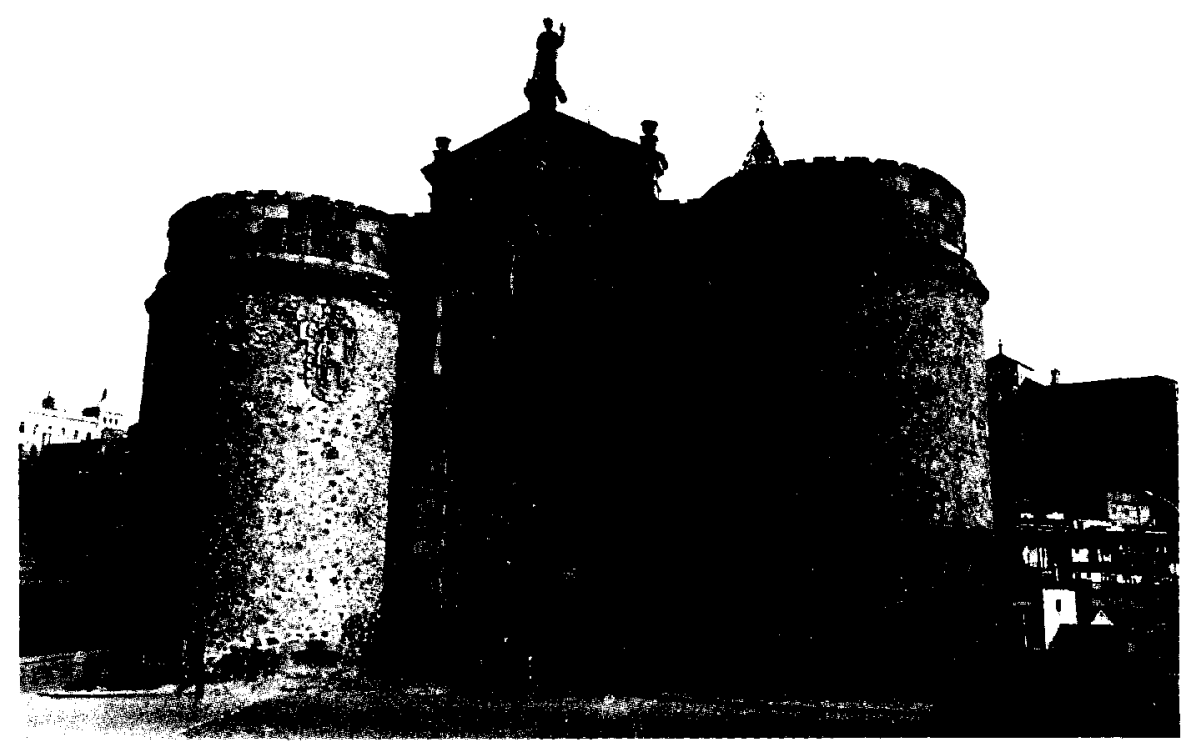

Fig. 4. Puerta de Bisagra. Toledo.

flejo fiel de los planteamientos que a fines de siglo se manejaban en materia de fortificación- aconsejara en su tratado utilizar lo más posible la muralla vieja, reformándola, y derribar las menos casas y templos posibles, así como no tirar la muralla vieja hasta no tener hecha la nueva ${ }^{15}$. Estaba reflejando uno de los problemas que plantearon siempre las nuevas fortificaciones, como fue el de la destrucción de casas y edificios religiosos. De cada una de las nuevas fortificaciones se podría hacer una historia con el tema de las destrucciones. En este sentido es muy gráfica la manera de expresarse de los representantes de la ciudad de Ibiza en 1588 , quejándose de la falta de dinero e informando de que del patrimonio real se estaban pagando "las casas y campos por donde la fortificación a pasado que se an derribado" ${ }^{16}$. Efectivamente, una fortificación arrasaba el lugar por el que "pasaba", tanto por los nuevos muros y baluartes que se construían como por el terreno libre que necesitaba dentro y fuera para

15 Rojas C. de, op. cit, fol. 77-78.

16 AGS, GA, leg. 227. fol. 245. 


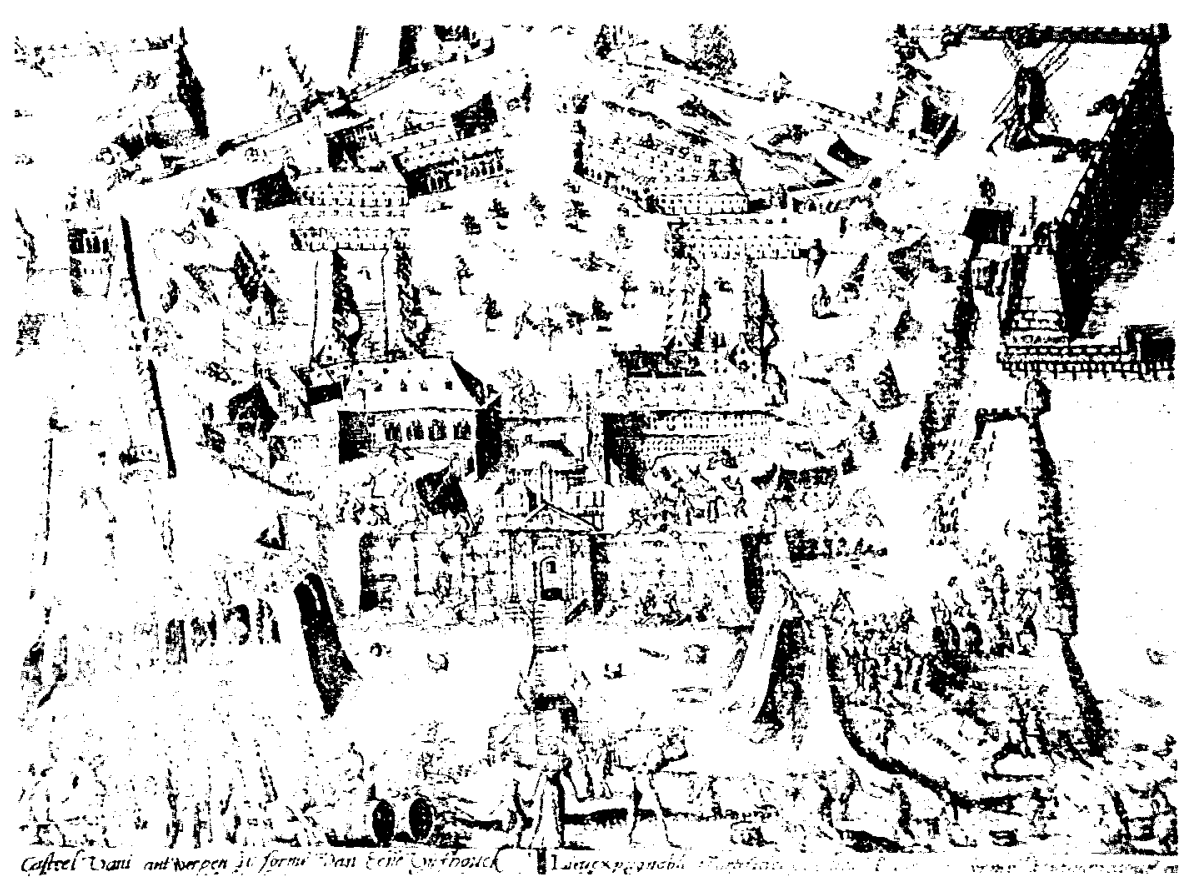

Fig. 5. La ciudadela de Amberes en un grabado de 1577. Archivo General de Simancas.

su seguridad. A veces en las trazas se indican las casas que se han de derribar, como se hace en un proyecto del siglo XVI para la fortaleza de Pamplona. Podemos comprobar también -en la traza propuesta para fortificar de nuevo Denia en 1575- lo agresiva que podía llegar a ser una fortificación con respecto a lo existente. A veces en cambio esta agresividad se convierte en adaptación, como sucedió con el proyecto de baluartes de Mallorca de 1606, que tienden a absorber el antiguo trazado urbano e incluso respetan la puerta en la que acababa uno de los ejes viarios preexistentes.

La importancia que tuvieron las fortificaciones de Cádiz dado su enclave estratégico, las convierten en uno de los mejores ejemplos de los problemas que planteó la fortificación de una ciudad con fines defensivos en la España del siglo xvi ${ }^{17}$. La vista que de la ciudad hizo Wyngaerde

17 Sobre estas fortificaciones, Fernández Cano, V., Las defensas de Cádiz en la Edad Moderna. Sevilla 1973. 


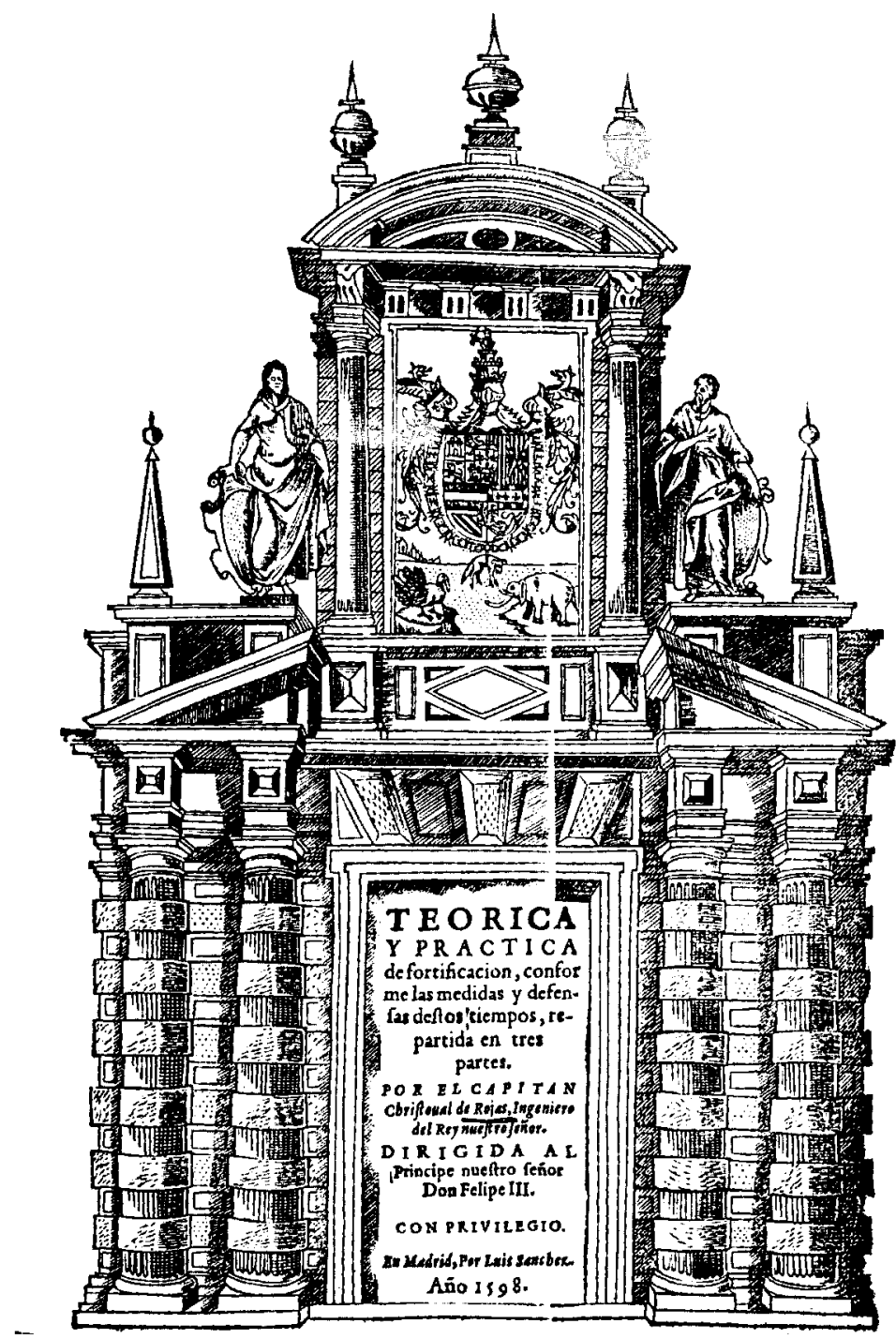

Fig. 6. Cristóbal de Rojas, Teórica y práctica de fortificación. Madrid 1598. Portada. 


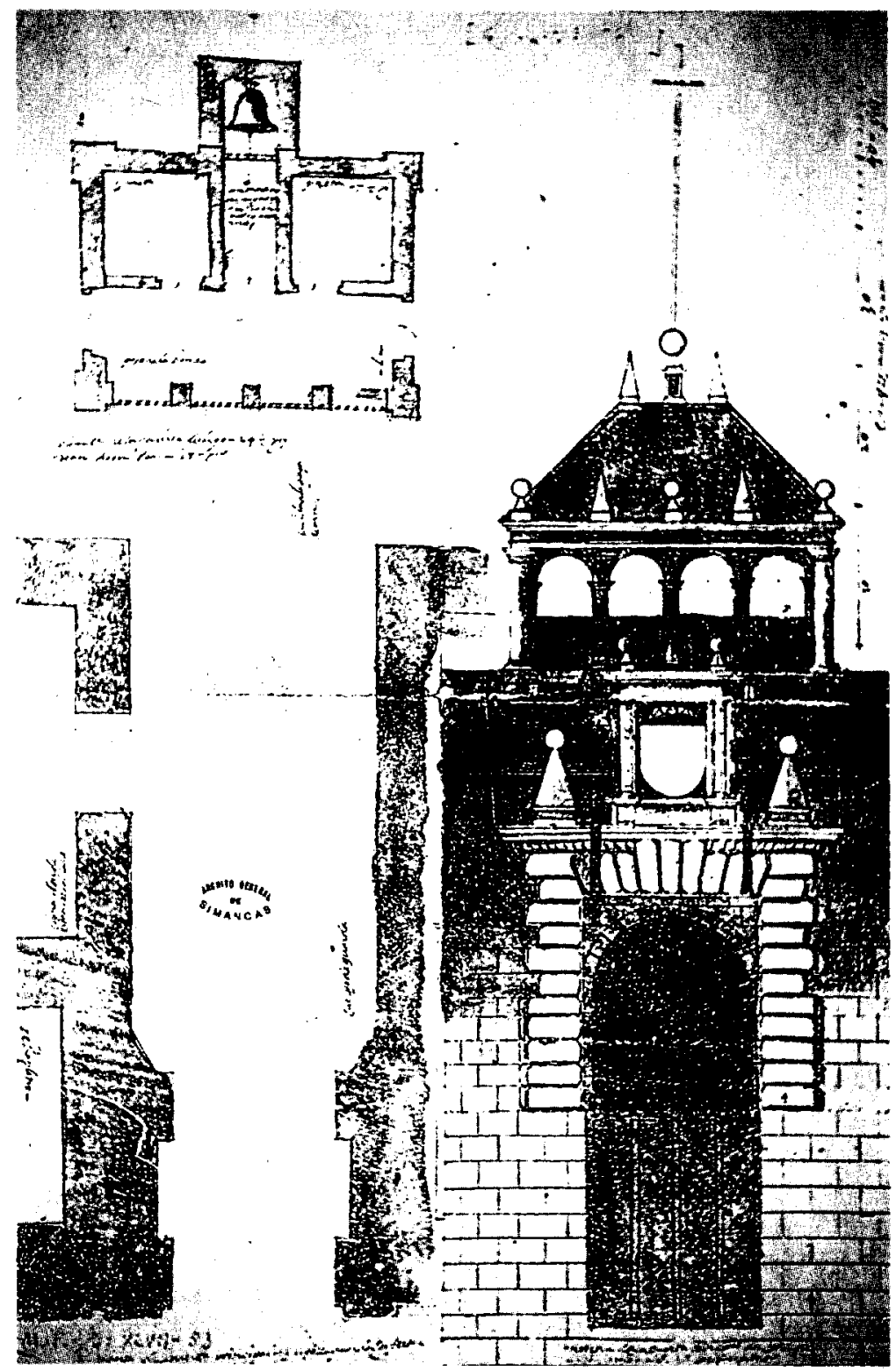

Fig. 7. Portada del castillo de Jaca, "Conforme a la de Pamplona". 1613. Archivo General de Simancas. 


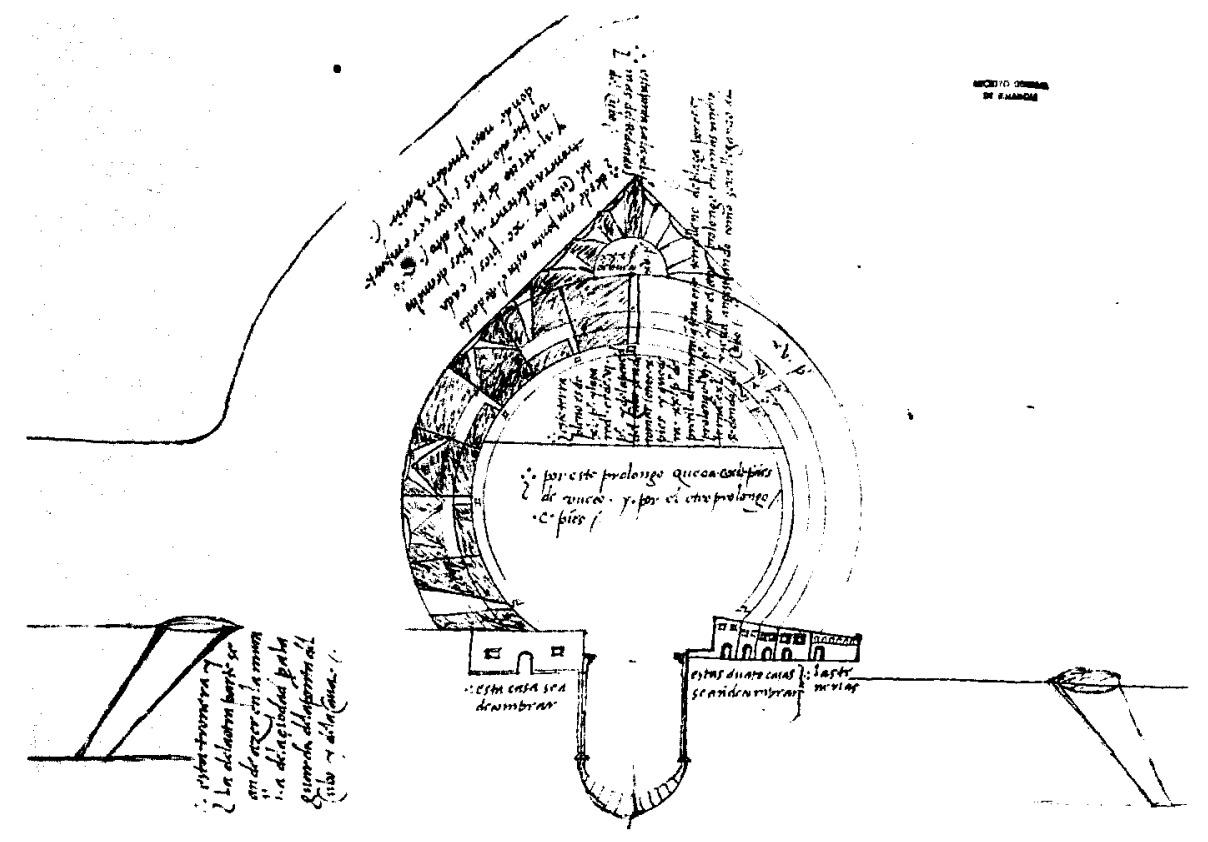

Fig. 8. Proyecto de reforma de la fortificación de Pamplona en el siglo xvi, en el que se indican las casas que hay que derribar para hacer el nuevo cubo. Archivo General de Simancas.

en 1567 refleja hasta qué punto los nuevos baluartes contribuyen a modificar la imagen urbana. Es la única ciudad que Cristóbal de Rojas -que trabajó en ella muchos años- representó en su tratado, "codificando» así lo que era el resultado de la experiencia y elevando su propia propuesta de fortificación para esta ciudad a la categoría de modelo.

Al hablar del tema de la fortificación en tanto que elemento urbano por şu influencia en el desarrollo de algunas ciudades españolas en este siglo, es obligado citar a Vespasiano Gonzaga quién, junto con el ingeniero Fratín, tomaría por ejemplo en 1571 la decisión de no ampliar la fortificación de San Sebastián, con las consiguientes repercusiones que esto pudo tener para el crecimiento de la ciudad. Al tratarse de un personaje como Vespasiano Gonzaga, que intervino en las grandes decisiones tomadas en materia de fortificación para muchas ciudades durante los años que estuvo en España, las resonancias urbanas aumentan pues la ciudad fue para él tema de reflexión como atestigua la pequeña "Atenas" que quiso recrear al construir la ciudad de Sabbioneta en Italia, cuyos muros fueron construidos por el ingeniero Girolamo Cataneo, uno de los teóricos 


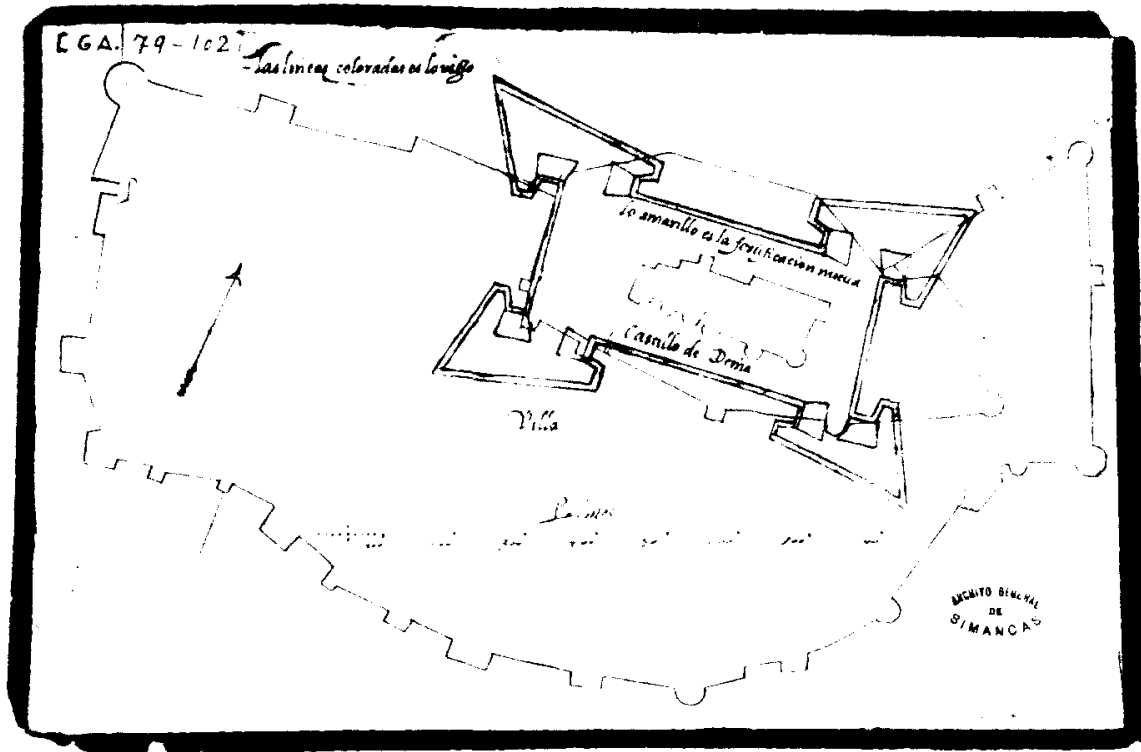

Fig. 9. Proyecto de fortificación para Denia en 1575, en el que se puede apreciar lo agresivo de la nueva fortaleza frente al perímetro existente. Archivo General de Simancas.

más manejados en España y fuente de autoridad, por ejemplo, para Castillo de Bobadilla en su Política para corregidores.

Los ingenieros tuvieron un papel determinante en la evolución urbana de aquellas ciudades que fueron episodios del engranaje defensivo de la península. Aparte de casos ya citados, podemos recordar la intervención de Fratín y Antonelli en 1576 en Cartagena ${ }^{18}$, o los problemas de índole urbana que planteó la nueva muralla para Santiago de Compostela proyectada a fin de siglo ${ }^{19}$. A veces los ingenieros tuvieron ocasión de intervenir como urbanistas, al margen de las intervenciones que generaba la construcción de las nuevas cortinas y baluartes, como es el caso de Spannocchi, que dio un trazado para Guetaria en 1597, después de que ésta fuera destruida por un incendio.

18 AGS, GA, leg. 88, fol. 164.

19 ldem, leg. 431 , fol. 59. 

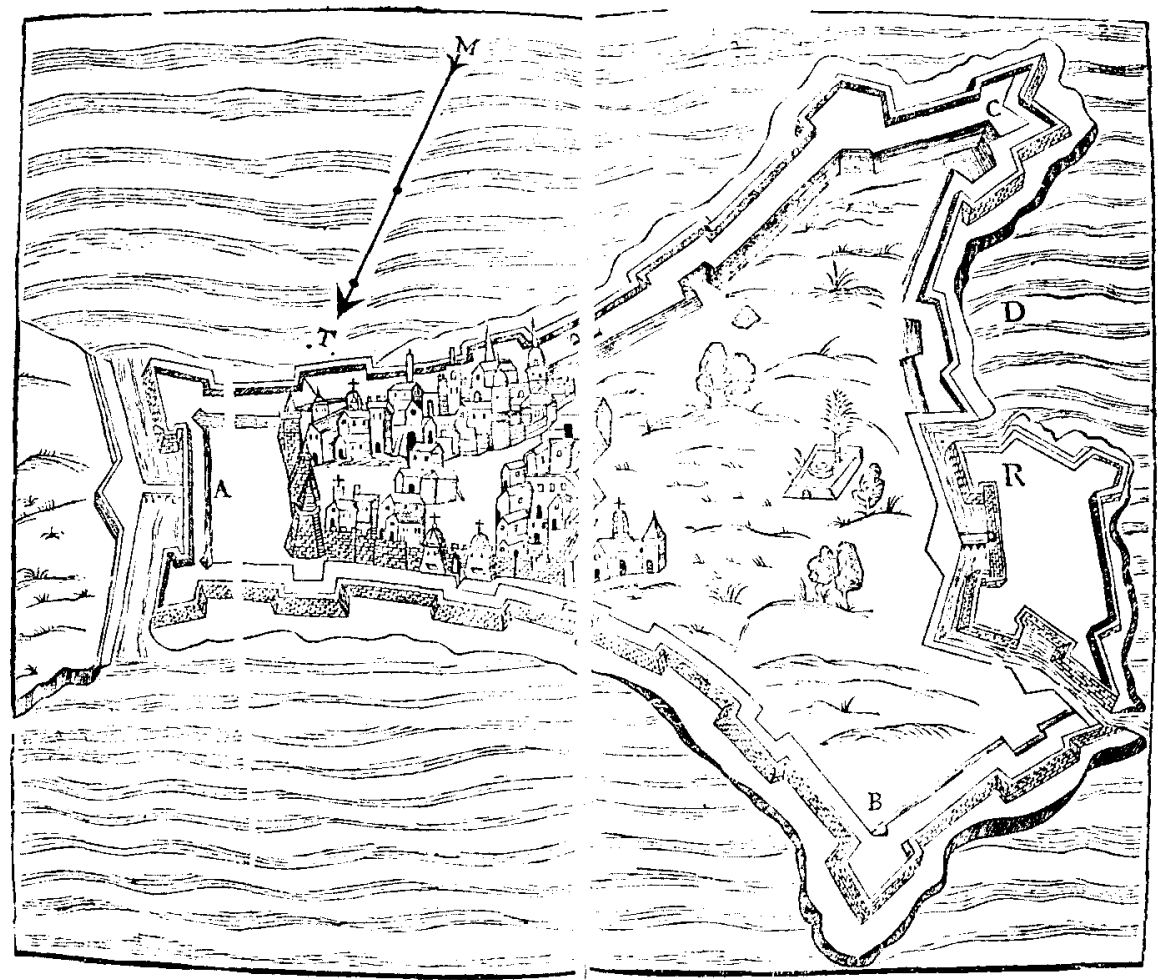

Fig. 10. Cristóbal de Rojas, Teórica y práctica de fortificación, Madrid, 1598. La planta de la ciudad sería la de Cádiz, en la que el autor trabajó como ingeniero muchos años.

Las murallas fueron absolutamente necesarias en las poblaciones expuestas a posibles ataques, asi que fue en éstas en las que de una manera más clara la fortificación se pudo convertir en un problema urbano y los ingenieros en los técnicos capaces de solucionar y ordenar el crecimiento de la ciudad. Por ejemplo, de Motril a comienzos del xvII se decía que era "un casar avierto", con el peligro que ello suponía, al haber crecido sin un perímetro fortificado; con anterioridad al levantamiento de los moriscos la iglesia mayor había sido, con sus dos baluartes, la fortaleza de la villa - cuyas casas además estaban edificadas «a Casamuro"- pero luego se habían hecho calles en torno a ese núcleo fortificado y el arzobispo de Granada había ordenado derribar uno de los baluartes de la iglesia para edificar la capilla mayor. Por todo ello, y para que se siguiera 


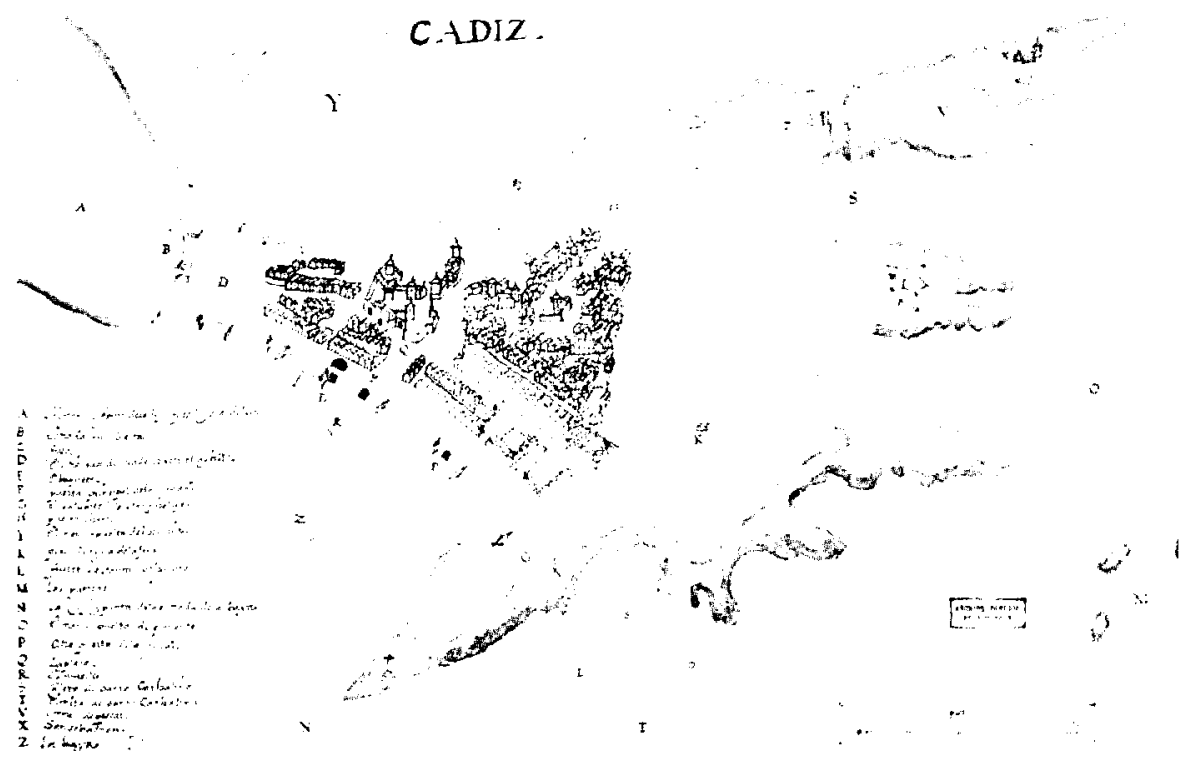

Fig. 11. Planta de Cádiz en 1609. Archivo General de Simancas.

un orden en el crecimiento de la villa, se pedía en esas fechas un ingeniero que diera la planta y la forma de construir ${ }^{20}$.

A veces nuevas construcciones defensivas dieron lugar a núcleos urbanos o permitieron el ensanche de otros. Es el caso de Estepona en 1587, donde se estaba haciendo un urreducto y baluarte", que alargaba el que había antes, con lo que quedaba sitio para hacer nuevas casas. Como vendiéndolas a censo el dinero así adquirido se podría emplear para reparar la fortificación y tenerla bien provista de municiones y artillería, se decidió hacer diecisiete casas dejando una plaza de armas de ochenta pies de ancho y ciento veinte de largo ${ }^{21}$. Estas medidas respetan exactamente las proporciones que para la plaza de las ciudades de Indias se habían dado en las Ordenanzas de 1573: "que la plaça sea en quadro prolongada que por lo menos tenga de largo una vez y media de su ancho", y son por tanto una de las muchas pruebas de que la ciudad hispánica del siglo XVI ha de ser estudiada sin convertir al Atlántico en

20 Servicio Histórico Militar. Colección Aparici, tomo XXII, págs. 16-20.

21 AGS, GA, leg. 202, fol. 72 . 


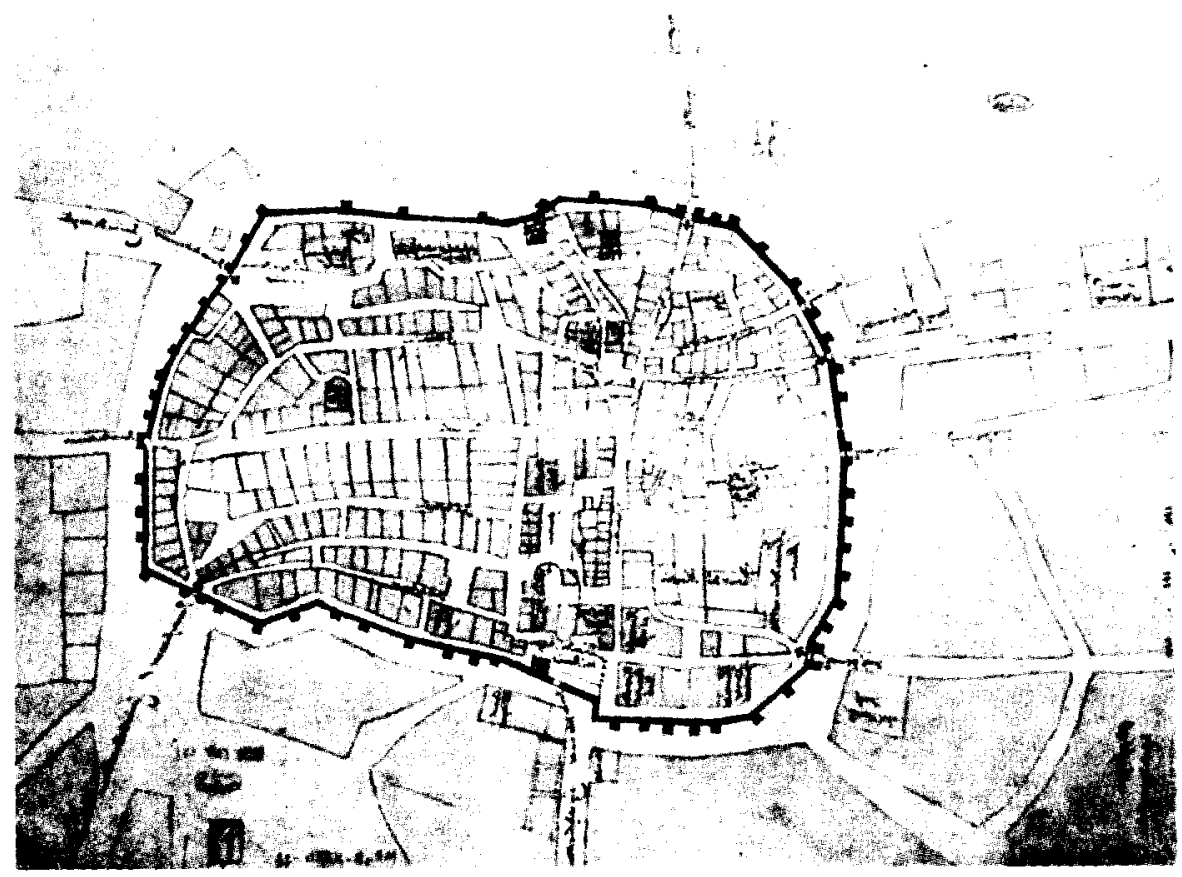

Fig. 12. La ciudad de Santiago de Compostela, con su trazado y la muralla con sus nueve puertas, que acompañaba a la carta y memorial del arzobispo sobre su defensa en 1595. Archivo General de Simancas.

una frontera divisoria, como a veces se hace quizá por la magnitud del proceso de construcción de nuevas ciudades en el Nuevo Mundo.

A la hora de fortificar una ciudad, los problemas con la iglesia fueron constantes, no sólo por la necesidad de derribar monasterios - tantas veces extramuros de la cerca anterior- para levantar unas nuevas fortificaciones, sino también porque a veces la iglesia fue un motor de crecimiento desde el punto de vista espacial, que "saltó" por encima de las murallas. Esto, que no era un problema cuando no se trataba de una ciudad de frontera, podía suponer un peligro en otros casos, tal como ocurrió en Almería. Sobre esta ciudad informaba el conde de Tendilla en 1549 que la gente había abandonado la protección de las antiguas murallas de la almedina desde que el obispo había comenzado a edificar la iglesia mayor fuera de ellas; proponía reparar únicamente las viejas murallas para que a la gente no le quedara más remedio que volver a la almedina, aunque se perdieran los edificios y casas que habian hecho 


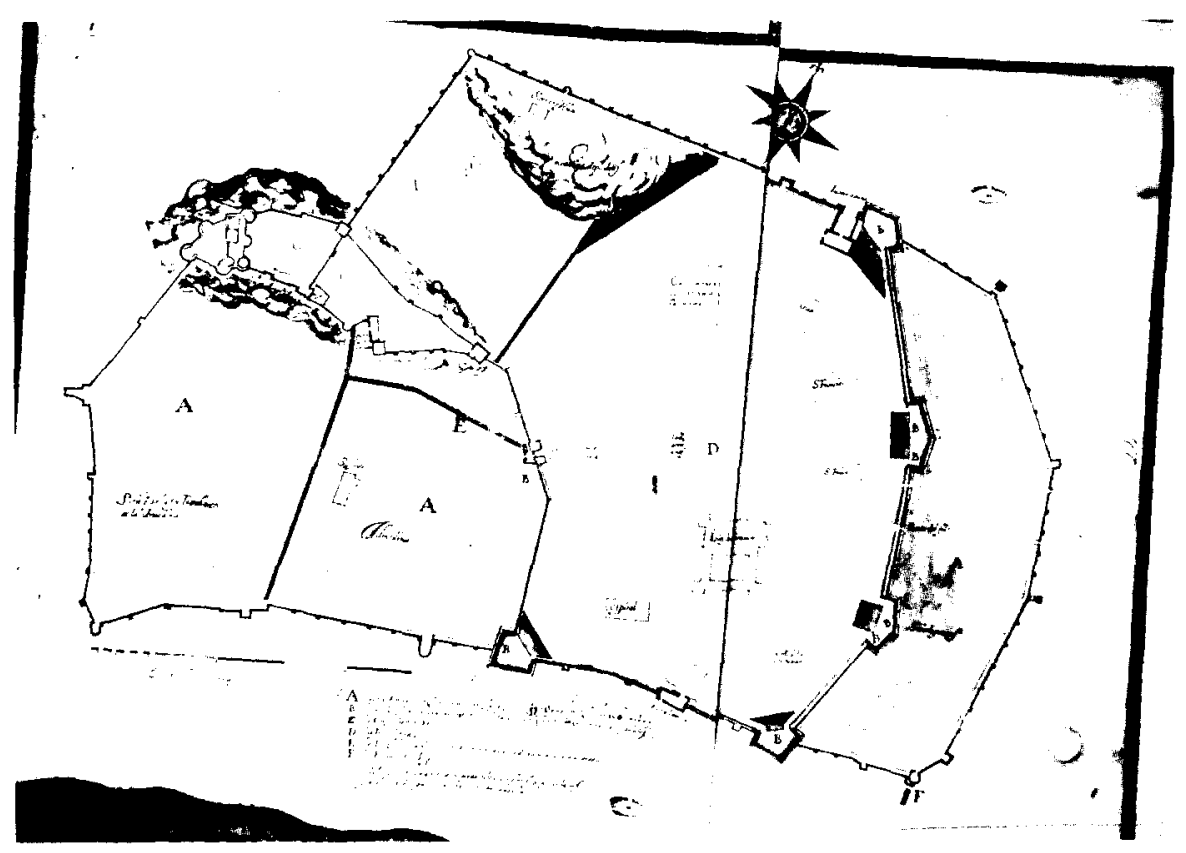

Fig. 13. Planta de la ciudad de Almería en 1621 por Juan de Oviedo.

fuera ${ }^{22}$. No se hizo así y a finales de siglo no quedó más remedio que fortificar el nuevo núcleo de población nacido en torno a una catedral que en su espléndida arquitectura fortificada expresa las circunstancias históricas en que fue construida. En los años 1592-93 se estaba haciendo el reducto entre la puerta de la mar y la de Purchena, habiéndose derribado para ello siete casas de particualares ${ }^{23}$. De 1621 es el plano de la ciudad realizado por el ingeniero Juan de Oviedo, en el que los nuevos baluartes están señalados con una doble "B" y los que faltaban por hacer con una sola "B", lográndose así un nuevo recinto fortificado acorde con los nuevos tiempos para defender esa zona de la ciudad nacida en el XVI, en la que además de casas principales, como la de doña Luisa Briceño de la Cueva, había ya un hospital y varios conventos e iglesias.

En casos de ciudades menos vulnerables a ataques -o que sólo en circunstancias excepcionales podían sufrirlos- las murallas no se llegaron 


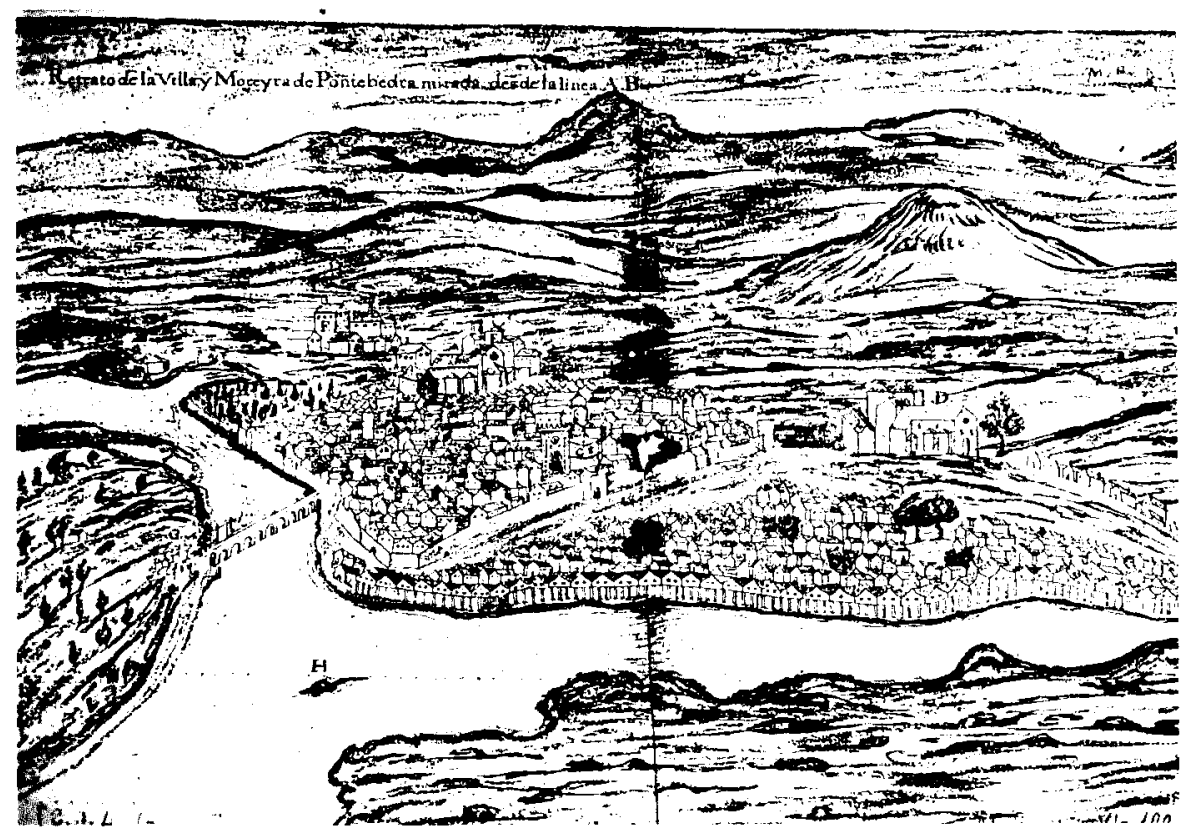

Fig. 14. Vista de Pontevedra en 1595. Archivo General de Simancas.

a renovar a pesar de haber sido objeto de discusión su posible defensa. Es el caso de Pontevedra - «lugar de muy buenos edificios assi de templos, como de casas, Plaças fuentes y jardines" ${ }^{24}$ - que en 1595 tenía un arrabal casi tan grande como la ciudad que guardaba la cerca. Vivía en el arrabal la gente del mar que, se decía, eran de los más ricos del reino y se había comenzado a formar otro núcleo de población, que llamaban "el Burgo", al otro lado del puente. Todo ello resultaba muy inconveniente para plantear una nueva fortificación a pesar de que el muro existente era de "mala forma y ruin fábrica», por lo cual se aconsejaba dejar la ciudad tal como estaba por el momento ${ }^{25}$. Estos informes se habían producido a raíz del ataque inglés de 1589 que obligó a emprender obras de fortificación en Galicia. Como consecuencia de ello, lo que sí se intentó fortificar fue La Coruña para lo cual hizo Spannocchi cuatro proyectos que se diferenciaban por la inclusión o no del arrabal de la

24 AGS, Mapas, Planos y Dibujos, VI-101.

25 Idem, VI-99. 
Pescadería dentro del nuevo recinto. Todavía en el siglo XVII se reclamaba que se fortificara de una vez la ciudad, de ser posible según el proyecto que incluía dentro de la muralla todo el arrabal ${ }^{26}$. De nuevo los problemas planteados por las fortificaciones nos permiten conocer mejor cómo eran las ciudades españolas de esta época.

Otra cuestión sobre la que hay gran cantidad de documentación es la de las casas construidas en las ciudades aprovechando las murallas, cosa que, aunque prohibida por las leyes, era raro que no se produjera. En Pontevedra por ejemplo el miedo a que los ingleses pudieran dirigirse a ella desde La Coruña en 1589, obligó a plantear el derribo de las casas que se habían construido pegadas a la muralla por la parte de fuera de ésta "para que el enemigo no halle escalas hechas". Una de las casas llevaba hecha más de cincuenta años y, una vez derribada, la dueña reclamó pidiendo indemnización y que se la reconstruyeran ${ }^{27}$. En las mismas fechas -el ataque inglés fue el detonante para la alarma en Galicialos vecinos de Santiago de Compostela protestaban de que se les obligara a derribar las casas del arrabal y las que estaban pegadas a la muralla de la ciudad ${ }^{28}$. Un año antes el Consejo de Guerra era informado de que los vecinos de Vitoria "dan peticiones en el ayuntamiento pidiendo se les de licencia para hazer casas junto a los muros y derribarlos y abajarlos, las quales se dan con mucha facilidad por el dho ayuntamiento", a pesar de que era una ciudad frontera de Francia y de Navarra, por lo que se pedía una Real cédula para impedir que eso siguiera sucediendo y en cambio se pudieran derribar las casas que perjudicaban a los muros ${ }^{29}$. Los ejemplos de esta invasión de los muros defensivos por el caserío podrían multiplicarse, pues se dio en todas las ciudades aunque sólo se convirtiera en problema para el Consejo de Guerra en aquellas que con mayor probabilidad podían ser atacadas.

\section{MURALLAS PARA LA PAZ}

Hasta ahora hemos ido viendo algunas de las intervenciones llevadas a cabo en las ciudades con fines defensivos, pero hubo otras murallas

26 Sobre estas fortificaciones, así como sobre el fuerte de San Antón realizado sobre una fortaleza anterior a partir de 1588 para defensa del puerto, Soraluce Blond. J.R. Castillos y fortificaciones de Galicia. La arquitectura militar de los siglos XVI-XVIII. La Coruña 1985.

27 Archivo Municipal de Pontevedra, leg. 77.

28 AGS, GA, leg. 270 , fol. 4

29 Idem, leg. 239, fol. 167. 
que se quedaron en mero proyecto (al fin y al cabo no eran tan necesarias) y que atendieron a otros fines además de a los de defensa.

En primer lugar habría que hacer referencia al proyecto del ingeniro Spannocchi de una nueva muralla para Sevilla porque, aunque data del año 1604, es el resultado de una actividad y una concepción de la ciudad que corresponde al siglo xVI. Su proyecto forma parte del parecer que dio ese año sobre cómo acabar con las inundaciones del río Guadalquivir. Para ello había hecho una descripción de la ciudad, acompañando a la relación una traza que hoy no conocemos. Se opuso a desviar el río con el argumento de que si se hacía asi la ciudad perdería la grandeza que le daba la contratación que tenía gracias a éste. Denunciaba también algo que, como acabamos de ver, era muy frecuente en todas las ciudades: que la gente particular se hubiera «apoderado" de la muralla de la ciudad, pegando a ella sus casas, abriendo puertas, etc., lo cual fue -en el caso de Sevilla- una de las causas de los grandes destrozos causados por la inundación.

Lo que habían ocupado los particulares era la parte de la muralla entre la Puerta Real y la torre del Oro. Entre ambos edificios había tanto almacenes de la ciudad como algunas casas de flamencos y todo se había inundado. Como además, según Spannocchi, esta parte de la ciudad era la más susceptible de ser atacada desde el arenal que tenía delante, proponía hacer en esta parte una nueva muralla con plataforma para la artillería, escarpada en su parte inferior - a ser posible con obra de cantería en la parte que iba a mirar al río- y a plomo el resto. Había que hacer también nuevas puertas pero, eso sí, en el mismo lugar de las que existían. Al tratarse de una muralla que con toda probabilidad no iba a servir para defensa - se trataba sólo de proteger a la ciudad de las avenidas del río- afirmaba que bastaba con hacerla de diez pies de alto.

Otro tema de especial interés para el tema de la ciudad se introduce en el proyecto: el hecho de que la nueva muralla se financiaría en parte vendiendo terreno para casas y almacenes en el espacio vacío que iba a quedar entre la muralla vieja y la nueva, así como en el terreno que quedara entre ésta y el río. Como el fin último era precisamente el de impedir los desastrosos efectos de las inundaciones, es esencial en el proyecto de Spannocchi la idea de abrir dos grandes arcos por los que pudieran pasar las avenidas, así como hacer una máquina, que había sido descrita por Vitruvio, para desaguar, de lo cual se podría encargar el maestro mayor Juan de Oviedo. Dicha máquina se había hecho ya en otros lugares - "y por que es maquina conocida... no me alargo en mas particular declaración", dice Spannocchi- lo cual constituye un dato más sobre la difusión y manejo del texto vitruviano en la España del siglo xvi. Con esto 
cerramos este resumen de algunos de los temas tratados en el largo informe del que la propuesta de una nueva muralla forma parte ${ }^{30}$.

En el caso de esta muralla para Sevilla, que no se llegó a hacer, además de una hipotética función defensiva (muy remota, pues el «baluarte" de Sevilla era Cádiz), se buscaba una utilidad pública como era la de paliar los devastadores efectos de las inundaciones. Sin embargo, en el caso de Madrid, que ahora vamos a ver, su significado como capital de la monarquía condicionó los planteamientos de la propuesta de una nueva muralla... que tampoco llegó a hacerse ${ }^{31}$.

La propuesta se debió a Cristóbal Pérez de Herrera, que habia sido protomédico de las galeras de España, pero cuyos intereses no se limitaron a la salud pública, sino que podemos hablar de él como del más interesante urbanista del fin de siglo. Conocedor de la arquitectura tal como demuestra en varios de sus escritos, su obsesión fue que Madrid se convirtiera en una ciudad a la altura de su grandeza como capital de la monarquia. Su trabajo fue reconocido por el mismo rey quien - según cuenta el mismo Pérez de Herrera- en su lecho de muerte le animó a continuar con sus desvelos por su utilidad al "servicio de Dios y bien público" ${ }^{32}$. Su fama - sobre todo por el hospital que se construía en Madrid a fines de siglo gracias a su esfuerzo- llevó su nombre hasta las páginas de la tantas veces citada ya Política para Corregidores de Castillo de Bobadilla ${ }^{33}$.

De 1597 data la propuesta de Pérez de Herrera para hacer una nueva muralla para Madrid ${ }^{34}$. Una vez más encontramos que uno de los problemas planteados es el de la gran cantidad de casas que se habian construido pegadas a la vieja muralla, pues en algunas zonas iban a impedir derribar esos viejos muros para emplear su piedra en los cimien-

so Spannocchi, T., Parece que dio el comendador... a la muy noble... ciudad de Sevilla sobre los Reparos que convienen para la inundación del Río Guadalquivir. Sevilla 1604.

31 Sobre los proyectos de amurallar Madrid a fin de siglo, he vuelto a escribir recientemente, "Modelo urbano y obras en Madrid en el reinado de Felipe 11 ", Actas del Congreso Madrid en el contexto de lo hispánico desde la época de los descubrimientos. Madrid 1992, y «El siglo xvI. La corte y el castillo» en Castillos, fortificaciones y recintos amurallados de la Comunidad de Madrid. Madrid 1993.

${ }^{32}$ "Carta apologética del Doctor Crístóbal Pérez de Herrera... al Doctor Luis del Valle... 1 de noviembre de 1610", CODOIN, tomo XVIII. Madrid 1851, págs. 564-574.

33 Castillo de Bobadilla, op. cit., pág. 683.

${ }^{4} 4$ Pérez de Herrera, C., Discurso a la Católica y Real magestad del Rey D. Felipe nuestro Señor, en que se le suplica, que considerando las muchas calidades y grandezas de la villa de Madrid, se sirva de ver si convendría honrarla, y adornarla de muralla, y otras cosas que se proponen, con que mereciesse ser Corte perpetua, y assistencia de su gran Monarquía. Madrid 1597. 
tos de la nueva muralla. Ésta, a excepción de los cimientos, sería de ladrillo y cal y la traza debería darla el arquitecto Francisco de Mora "y otras personas que entiendan y traten de fortificationes». En palabras de Pérez de Herrera, esta nueva muralla había "de servir por aora mas de ornato y guarda, que de gran fortaleza y defensa". Son estas palabras precisamente las que hacen de esta propuesta una excepción en el panorama internacional de las fortificaciones de la época: una muralla para ornato.

Dado este planteamiento no ha de extrañar que las puertas fueran algo fundamental y no olvida por tanto indicar que había que hacer puertas -algunas de triple arco- en las entradas principales a la villa: calle de Atocha, carrera de San Jerónimo, calle de Alcalá, calle Hortaleza, puente de Segovia y puerta de Toledo, con lo cual las entradas a Madrid tendrían la grandeza que requería el hecho de ser sede de la corte. Por lo que se refiere a los muros, no deberían ser muy altos pero gracias a ellos los vecinos se sentirían seguros, se podría controlar con mayor eficacia la entrada y salida de mercancías y —en caso de necesidad- se podría reformar para que sirviera también como defensa ${ }^{35}$. Es sin embargo la idea del ornato, tal como hemos hecho notar ya, la que preside la propuesta, pues incluso indica Pérez de Herrera que en la zona del alcázar se debía hacer especialmente baja, tanto para servir de "grande ornato" a este edificio, como para no impedir la vista que desde él se tenía de la Casa de Campo.

Madrid no necesitaba una muralla para la guerra por encontrarse en el centro de la península. El mismo autor er otro de sus escritos recuerda

${ }_{35}$ Por ser un buen resumen de algunos de los beneficios que una muralla reportaba a cualquier ciudad, reproducimos una pequeña parte de este texto de Pérez de Herrera: “... en la ciudad cercada biven los vezinos della con más seguridad de sus vidas, porque en ocasiones de peste no la entra nadie de parte donde ay contagios: sabese asimismo que mercaderías y mantenimientos entran y salen, para con más facilidad cobrar las rentas y alcavalas dellas sin notable fraude, y entiendese más fácilmente en ocasiones de delitos atroces el modo de descubrirse quien los hizo, acudiendo y tomando las puertas de la ciudad, teniendo también noticia de si entran o salen espías de enemigos, passando por parte pública y contada: fuera de que la muralla en todos los lugares del mundo sirve de guarda y reparo contra los enemigos que se pueden ofrecer en diferentes siglos y tiempos, pues siendo la que se fabricare fuerte de cimientos, y de latitud bastante, será fácil adelante en ocasiones de guerras, si les pareciere a los Reyes descendientes de V.M. y del Príncipe nro Señor, fortificarla, levantandola más, y edificándole algunos castillos en las partes que convenga, hazerla casi inexpugnable». Op. cit., fols. 17 y $17 v^{\circ}$

${ }_{36}$ Sobre ésto, así como sobre otras propuestas para amurallar Madrid, mi articulo «Modelo urbano...", cit. en nota 31 . 
que, al igual que el corazón está en el centro, también el rey debe estar en el centro de su pueblo para gobernarlo, 10 mismo que el sol está en medio de los cielos, Precisamente la ubicación geográfica de Madrid, convertida en símbolo por escritores como Pérez de Herrera ${ }^{36}$, hizo posible pensar en la fortificación como ornato de la ciudad. 
